\title{
Assessment of Value Chain for Honey and Beeswax Initiatives in Zanzibar
}

\author{
Samira Makame Juma, Abdalla Ibrahim Ali, Sara Abdalla Khamis, Rashid Juma Rashid, \\ and Mohamed Dhamir Kombo
}

\section{ABSTRACT}

\begin{abstract}
Honey and beeswax production in Zanzibar become important activities in raising livelihood income for rural communities. However, it is still difficult for the production yielded from these to contribute to fighting rural poverty. This research study is geared towards analyzing the performance and efficiency of the honey and beeswax value chain and its challenges in order to disclose opportunities and synergy for reducing income poverty to beekeepers in Zanzibar. The study conducted in Zanzibar focusing both Unguja and Pemba Island, covering two districts from each Island. Descriptive research using both qualitative and quantitative data obtained from primary and secondary sources. Questionnaire was administered to 120 respondents randomly and proportionally selected from beekeepers in four districts. Focus Group Discussions, Key Informant Interviews and Field visits were also conducted. Data were analyzed using Statistical Packages for Social Sciences (SPSS) versions 2016 with Excel Spread Sheet in Office 2016. The result revealed that, the major value chain activities involved were input supply, production, processing, marketing to final consumers. The actors identified were input supplier, producers, processors, traders, and consumers. The study also revealed that, majority $80.4 \%$ of beekeepers use traditional/ log hives which proved to give low yield in this study. The result also portrayed that, about $\mathbf{2 . 8 \%}$ of respondents that use Langstroth hives whereas $16.0 \%$ use top bar hive It was also found that annual average yield of honey per hive types was 9.09litres from traditional/log hive, 10 liters from Top bar hives and $\mathbf{1 6 . 8 5}$ litres from Langstroth hives. The price of unprocessed honey ranges from TZS 20,000 to 30,000 (9 to 14 US \$) per liter while processed honey is T.SH 35,000 to 40,000 (15 to 17 US\$) per litre. Various challenges were identified including inadequate supply of modern hive and equipment, climate change and variability, inadequate training and extension services, deforestation and forest fire, inversion of diseases pests and predator, lack of honey processing and marketing centre as well as capital. The profitability analysis indicates that, the annual net revenue per hive is TZS 203,347(US\$ 93) for traditional /log hive, TZS 227,166 (US\$ 103) for Top bar hive and TZS 342,536 (US\$ 156) for Langstroth hive.
\end{abstract}

Keywords: Beekeeping, Beeswax, Honey, Value chain, Zanzibar.
Submitted : November 30, 2021

Published : January 10, 2022

ISSN: $2684-1827$

DOI: 10.24018 /ejfood.2022.4.1.423

Samira Makame Juma

The State University of Zanzibar, Tanzania.

Abdalla Ibrahim Ali*

The State University of Zanzibar,

Tanzania.

(e-mail: abdalla.ibrahim ${ }^{\circledR}$ suza.ac.tz)

Sara Abdalla Khamis

The State University of Zanzibar,

Tanzania.

Rashid Juma Rashid

Zanzibar University, Tanzania.

Mohamed Dhamir Kombo

Zanzibar Agricultural Research Institute, Tanzania.

*Corresponding Author

\section{INTRODUCTION}

Beekeeping is well known in various parts of the world that provide a sustainable livelihood for small scale beekeepers and other rural people [1]. It plays a vital role in achieving millennium development goal for income generating and alleviating poverty [2]. Apart from being a source of income for the poverty reduction, beekeeping also plays a greater role in conservation of forest ecosystem and improvement of agriculture through pollination, hence improve crop yield [3].

In Africa, traditional honey and beeswax production is more common [4], [5]. Countries like Tanzania, Sudan, Uganda, and Somali mainly employ traditional methods of honey and beeswax production using traditional hives which are practiced it in a family level [6]. Beekeeping sector in Tanzania is estimated to employ about two million people and contribute to the national economy by generating about US\$
19 million per year [7]. Meanwhile in Zanzibar, beekeeping is estimated to provide employment to about 1,531 people in Unguja and Pemba as well as about 13.3 tons of honey are produced annually Unpublished [8]. The contribution of agriculture, Forestry and Fishing in Zanzibar GDP is estimated to reach $21.2 \%$ during 2019 [9]. However, honey and beeswax contribution to Zanzibar GDP is still negligible. Despite the fact that honey and beeswax production has been advocated as a major contributor for livelihood improvement and poverty reduction for rural people, without developing a well value chain and market access it will be difficult for the beekeepers to realize the likely benefit from this industry. Apart from the valuable benefits obtained from the beekeeping business and the effort made by Government and other actors in beekeeping sector in Zanzibar, the optimal yield still remain low [10]. Likewise, various challenges facing honey and beeswax production have been reported. These include deforestation, lack of capital and modern 
beekeeping equipment as well as pests and diseases [11]. These challenges may likely affect the entire value chain activities and hence reduces the performance of the honey and beeswax production thus affecting the income level of producers., So far there are no established clear indicators that explain the capacity of modern beehives in honey yield increases compared to traditional one [12] in study area. In this regard it is important to conduct this research to assess the situation at the grass-root level. Therefore, this study aims to assess value chain of honey and beeswax initiative and identify challenges that hinder the performance along its value chain from sourcing of input to the final consumers with a purpose of enhancing opportunities for income poverty reduction to beekeepers in Zanzibar. The essence of conducting honey and beeswax value chain is to establish a network between the value chain activities and the actors involved so as to meet the needs of the targeted producers and consumers. This is focused on the attainment of sustainable growth of honey and beeswax production to reduce income poverty for beekeepers.

\section{MATERIALS AND METHODS}

\section{A. Description of the Study Area}

The study was conducted in Zanzibar (Unguja and Pemba islands), covering four Districts including South and North B' in Unguja, Wete and Mkoani in Pemba island. In Unguja four Shehias were surveyed including Muyuni, Bwejuu, and Kitogani in South District located at $5^{\circ} 4^{\prime} 59.99^{\prime \prime}$ and longitude: $39^{\circ} 45^{\prime} 0^{\prime}$ " and Mafufuni in North ' $\mathrm{B}$ ' located at $39^{\circ}$ $40^{\prime}$ and $39^{\circ} 53^{\prime}$ longitudes East of Greenwich. Mkoani district located at Latitude $5^{\circ} 22^{\prime} 22.8^{\prime \prime}$ and Longitude $39^{\circ} 43^{\prime} 4.8^{\prime \prime}$. The study area has a tropical humid climate characterized by a bimodal pattern of rainfall with an average annual rainfall of $1,630 \mathrm{~mm}$. In Zanzibar there are two rainfall seasons - the long rains starting in March until June and short rains starting in October until December. The average temperature ranges

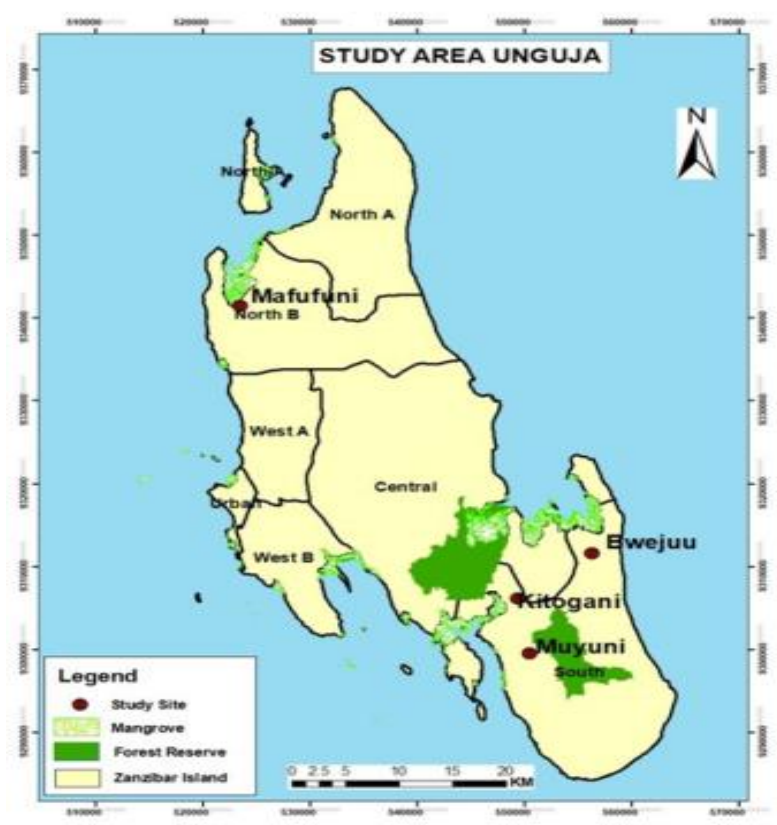

(a)

Fig. 1. Map of Unguja (a) and Pemba (b) between $24{ }^{\circ} \mathrm{C}$ to $28{ }^{\circ} \mathrm{C}$ with mean monthly maximum temperature ranges between $28{ }^{\circ} \mathrm{C}$ to $32{ }^{\circ} \mathrm{C}$ and minimum temperature ranges between $18{ }^{\circ} \mathrm{C}$ to $22{ }^{\circ} \mathrm{C}$ [13] These patterns and amount of rainfall and temperatures influence flowering of plants and in turn honey production in a given time period. The study areas (Fig. 1) were selected because these Districts inhabit a large number of beekeepers in Zanzibar and characterized by having a wider varieties of coral rag forests, mangroves and clove forests with varieties of nectar-producing species that constitute high production of honey and beeswax. In addition, the areas were selected on the bases of their accessibility for easy collection of data, time constraints and financial limitation.

\section{B. Methods for Data Collection}

In this study both primary and secondary data were collected in this study using the following tools.

\section{1) Household Interviews (HHI)}

Household interviews (HHI) were conducted to collect primary information from the beekeepers. A total of 120 questionnaires were designed and administered to collect information on a range of activities that are required to bring honey and beeswax value chain from supply of inputs, production system, processing, marketing, and honey distribution to the final consumers. It focused on the type of beehive owned, cost of beehive, honey production and harvesting season, honey and beeswax price were gathered. In addition, site selection for apiary, beehive management (inspection, swarm control and catching), methods of honey extraction, honey storage and packaging were also collected The interviews were developed to ensure cultural appropriateness and ethical consideration to reduce any cultural biases or misunderstandings. The interviews were held at locations at which the interviewees felt comfortable, and the time varied according to the availability of the interviewee.

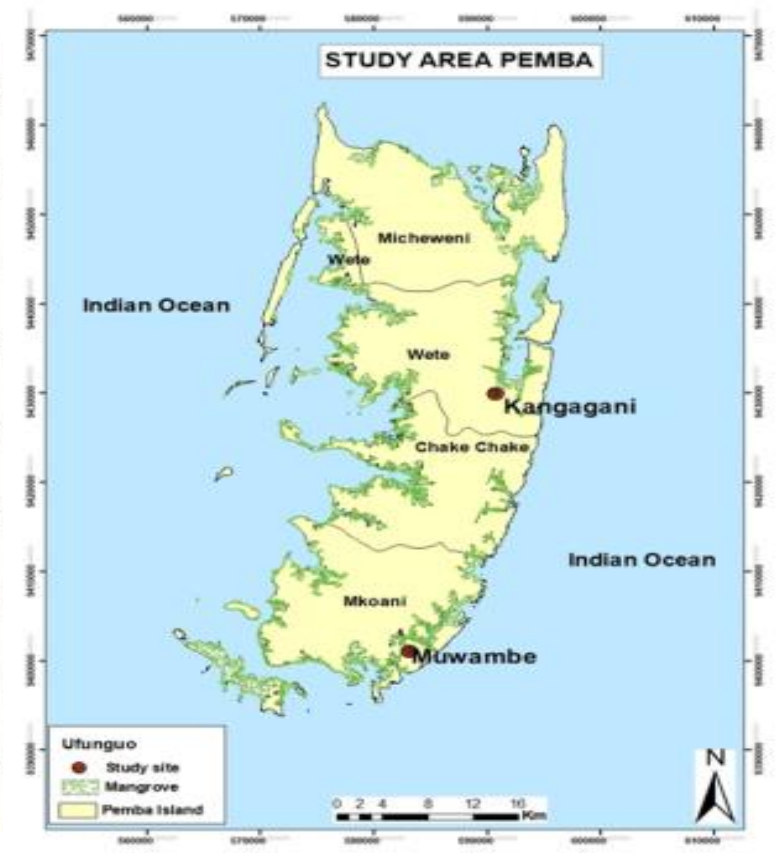

(b) 


\section{2) Focus Group Discussion (FGD)}

Four FGDs with beekeepers from the selected district were also conducted using guided questions to gather information on beekeeping practices and challenges faced by honey and beeswax production. It involves village leaders and individuals who have knowledge about the beekeeping practices, management systems, bee flora, and constraints of beekeeping in the area. The number of FGD participants were 5 for each group in each district which considered convenient to collect information to complement the survey work [14] Researcher facilitated the discussions to get experience on the activities involved in honey and beeswax value chain together with challenges that hinder the effective honey and beeswax value chain from input supply to end users of honey. This information cross-referenced to compare (verified) responses from interviews conducted at the household level.

\section{3) Key Informant Interview (KII)}

Key Informant Interview (KII) was used to collect information to selected individuals who are likely to provide information on beekeeping activities using checklist. A total of 5 key informant interview were conducted which involved Carpenter, Zanzibar Beekeeping Association (ZABA) Unguja, Pemba Beekeeping Association (PEBA) in Pemba, Beekeeping Officers (BO) who are working at district authorities, Shehia leaders (SL) and Government Officers (GO). The interview was designed to provide an insight on the availability for beekeeping inputs, type of beehives commonly used, price of honey, availability of programmes related to beekeeping and challenges were discussed.

\section{4) Field Observation ( $F O)$}

Field Observation (FO) was conducted in each district using checklist, apiaries were visited, and observed data were recorded. This technique was jointly applied together with the community members under the guidance of Beekeeping officer in charge. The data collected involved the types of beehives, places where beekeepers placed their beehive, evidence of uses of pesticide in agricultural farms near to apiaries, pests and diseases, and hive management. After observing these constituents, the data was recorded to strengthen the information on survey work. In addition, the problem of environmental destruction and evidence of fire and forest destructions were also observed and recorded. After discussion researcher also got opportunity to standardize the gathered information from field to get information about bee populations, honey yields and prices, honey processing methods, hive inspection practices and the comments were also documented. The information obtained from the field was used to validate the information obtained from the House hold interview and group discussion.

Secondary data was collected from various sources of literature to capture information based on what has been done or known in relation to honey and beeswax value chain and production in other places and its challenges to compare with this study. The information were obtained from different sources including internet, published documents from several relevant institutions and organizations at local, national and international level. Others was from academic papers, books, journals, and article related to this study. The information from literature was used to compare challenges, value chain activities and some results on honey and beeswax production.

\section{RESUlTS AND DiSCUSSION}

\section{A. Value Chain Activities of Honey and Beeswax in the Study Areas}

The result from (HHI) found that, the major value chain activities in honey and beeswax identified by respondents in study areas first is supplies of beekeeping input, (beehives, bee equipment and bee colony). Secondly is production which involves (site selection for apiary, placement of hives, management of beehives and harvesting of honey., Thirdly is processing which involves (filtering, packaging, storage, and labeling). Fourthly is Marketing and fifthly are final consumers of honey and beeswax as presented in (Fig. 2). The linkage of value chain activity seems relatively short in study areas and there is no restriction in performing these activities, everyone can perform multiple functions in the whole chain of operations in beekeeping.

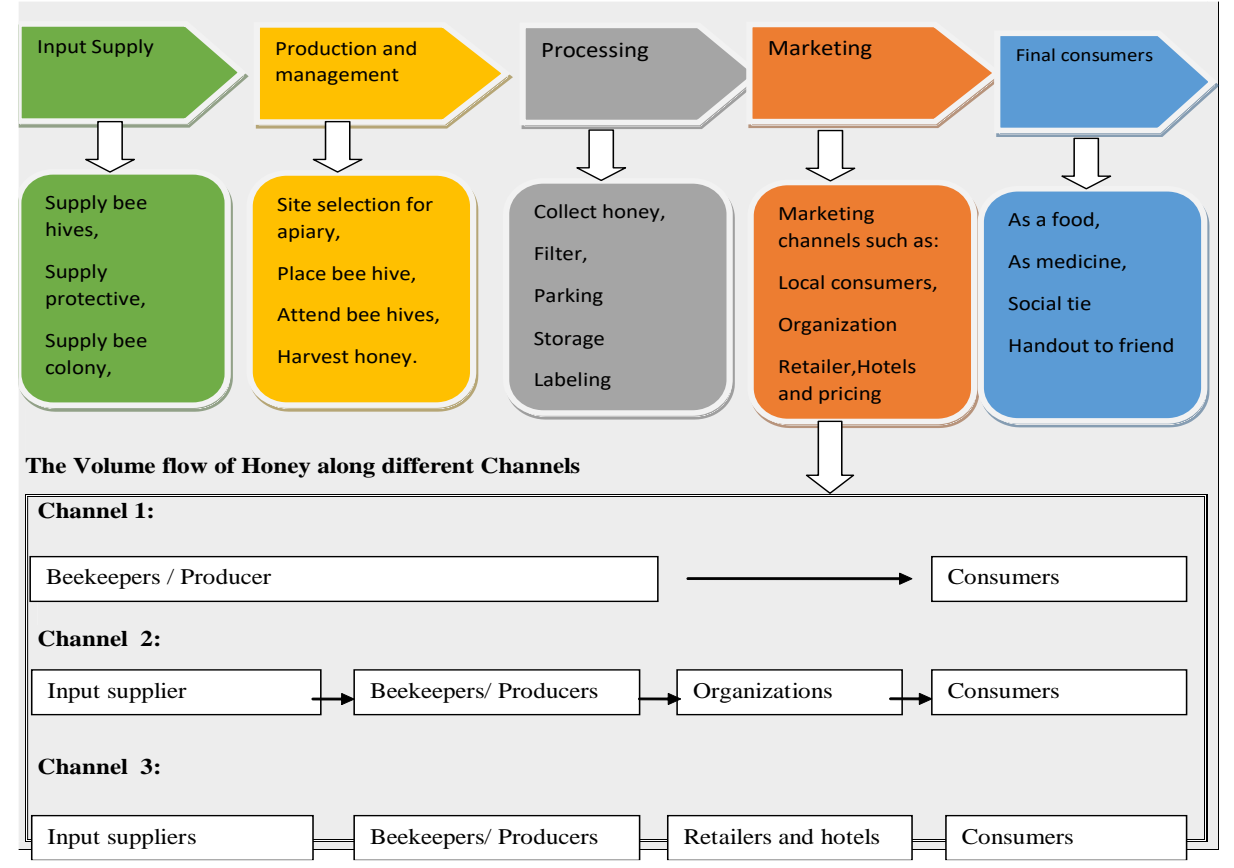

Fig. 2. Value chain diagram and flow of honey in study areas. 
The value chain activities on honey and beeswax are described below:

\section{1) Input supply}

Input supply forms the foundation of the honey and beeswax value chain activity. The result from Household Interview found that, the major common input includes beehives, bee protection and bee colony, hive management tools and honey processing machines. The study also found that, major supporters and suppliers of input comprise of Revolutionary Government of Zanzibar, International and local organizations as well as individual entrepreneurs engaged in the construction of beehives.

\section{2) Supply of beehives}

The Study also revealed that, about $2.8 \%$ of respondents use Langstroth hives, $16.0 \%$ use top bar hive while $80.4 \%$ beekeepers use traditional/ log hives as far as the study is concerned proved to give low yield. The study corresponds with [15] on his study on improving beekeeping in Unguja who portrayed that about $96.4 \%$ of beekeepers in Unguja use traditional/log hives in honey production. In addition, [16] reported that $95 \%$ of beekeepers use traditional beehives such as $\log$ hives and bark hives.

\begin{tabular}{cccc}
\multicolumn{4}{c}{ TABLE I: TYPES OF BEEHIVES USED PER DISTRICT } \\
\hline Name of District & $\begin{array}{c}\text { Traditional } \\
\text { hive \% }\end{array}$ & $\begin{array}{c}\text { Top bar } \\
\text { hive \% }\end{array}$ & $\begin{array}{c}\text { Langstroth } \\
\text { hives \% }\end{array}$ \\
\hline South District Unguja & 45.5 & 5.66 & 2.5 \\
North 'B' District Unguja & 0.48 & 0.9 & 0 \\
Mkoani District Pemba & 26.7 & 6.2 & 0.3 \\
Wete District Pemba & 7.6 & 3.2 & 0.1 \\
Overall Percentages & $\mathbf{8 0 . 4}$ & $\mathbf{1 6 . 0}$ & $\mathbf{2 . 8}$ \\
\hline
\end{tabular}

\section{3) Supply of protective gears}

The study found that $10.8 \%$ of the respondents received beekeeping tools and equipment from external donor, $33.3 \%$ uses traditional smokers $19 \%$ obtained from Government support, while majority $(36.7 \%)$ of respondents reported having borrowed the bee suit and smokers from other beekeeper during honey harvesting.

\section{4) Major supplier of beekeeping materials}

The results indicates that $52 \%$ of beekeepers have not support (self-sponsored), $22.5 \%$ of the respondents received support from Inductively Coupled Plasma Emission (ICIPE) particularly Langstroth hive and protective gears $19 \%$ receives support from the Revolutionary Government of Zanzibar, 4\% from Jozani Chwaka Bay Conservation Association (JECA) as well as $2.5 \%$ from Zanzibar Livestock Welfare Development Association (ZALUWEDA).

TABLE II: MAJOR SUPPLIER OF BEEKEEPING MATERIALS

\begin{tabular}{ccc}
\hline Supplies Langstroth hives & Frequency & Valid Percent \\
\hline *N/A & 62 & 52.0 \\
ICIPE & 27 & 22.5 \\
Government of Zanzibar & 23 & 19 \\
JECA & 5 & 4 \\
ZALUWEDA & 3 & 2.5 \\
Total & $\mathbf{1 2 0}$ & $\mathbf{1 0 0 . 0}$ \\
\hline
\end{tabular}

$* \mathrm{~N} / \mathrm{A}=$ Beekeepers who have not support (self-sponsored).

\section{5) Supply of bee colony}

The result found that, there is no common method of obtaining a bee's colony in Zanzibar, each beekeeper own way of obtaining colony, however, the result found that $27 \%$ of respondents obtain bees by transferring a colony from the wild into hives using special transfer hive and $73 \%$ get bee colony by set up a hive rubbed inside with beeswax to give it an attractive scent, and waiting for a passing swarm of bees to occupy it.

\section{B. Honey Production \\ 1) Site selection for bee apiary}

During the study, it was found that, majority (31.7\%) respondents keep their beehives in mangrove forests, $(26.7 \%)$ of respondents keep in coral rage forest, $(18.3 \%)$ respondents hung their hives on top of big tree like mango tree, (11.7\%) respondents keep their hives in both areas while (11.7\%) respondents keep their hives around home area particularly women to facilitate hive management (Table II).This result corresponds with [17] was reported that there is a specialty of honeys such as those collected near mangrove and cloves trees. Furthermore, it was reported that beekeepers from Florida often move their beehives close to mangrove forests because the bees make distinctively flavored honey from the nectar of the mangrove flowers [18]. In Cuba, also there is a tradition of moving thousands of bee colonies to mangrove during its long blooming season. In addition, the study done by [19] found that there is a positive relationship between the number of flowers and number of insect visits (including bees) for the four mangrove species namely Rhizophora mucronata, Bruguiera gymnorhiza, Ceriops tagal and Avicennia marina. This implies that mangrove areas are a favorable place for honey production.

TABLE III: SITE SELECTION FOR BEE APIARY

\begin{tabular}{cccccc}
\hline $\begin{array}{c}\text { Name of } \\
\text { District }\end{array}$ & $\begin{array}{c}\text { Around } \\
\text { home }\end{array}$ & $\begin{array}{c}\text { Coral } \\
\text { forest }\end{array}$ & $\begin{array}{c}\text { Mangrove } \\
\text { forest }\end{array}$ & $\begin{array}{c}\text { Hanging on } \\
\text { top of a tree }\end{array}$ & Both \\
\hline $\begin{array}{c}\text { Mkoani } \\
\text { Pemba }\end{array}$ & 2 & 5 & 10 & 7 & 4 \\
$\begin{array}{c}\text { North 'B' } \\
\text { Unguja }\end{array}$ & 2 & 3 & 9 & 0 & 0 \\
$\begin{array}{c}\text { South Unguja } \\
\text { Wete Pemba }\end{array}$ & 8 & 14 & 10 & 8 & 5 \\
Total & $\mathbf{1 4}$ & 110 & 9 & 7 & 5 \\
Percentage & $\mathbf{1 1 . 7}$ & $\mathbf{2 6 . 7}$ & $\mathbf{3 1 . 7}$ & $\mathbf{1 8 . 3}$ & $\mathbf{1 1 . 7}$ \\
\hline
\end{tabular}

\section{2) Honey harvesting seasons}

The results found that all respondents in all the districts reported of two honey harvesting seasons per year. The peak or high honey harvesting season was reported to be from October to November and the low season is noted between February to April in both Unguja and Pemba areas for traditional and top bar hives; while those who have modern Langstroth hives reported that they can harvest three times or more a year. This corresponds to the findings from [20] which reported that honey is being harvested twice a year from October to November and February to May. This implies that, majority of beekeepers harvest their honey twice a year using traditional hives while there is an opportunity to harvest three or more times using modern Langstroth hives

\section{3) Amount of Honey produced per type of hives}

The study found that, the annual average yield of honey per hive type was 9.09 litres from traditional/log hive, 10 litres from Top bar hives and 16.85 litres from Langstroth hives (Fig. 3). This finding is more or less the same as the study 
done by [21] in Ethiopia who found that Traditional beehives produce approximately 5 to $6 \mathrm{~kg}$ per year, while honey yield from Langstroth beehives on average ranges from 15 to 25 liters per year. In addition, [22] proved an average yield of $19.77 \mathrm{~kg}$ per hive with modern hives and $5.13 \mathrm{~kg} / \mathrm{hive}$ with traditional hives. This implies that,there is an opportunity to increase honey yield using modern Langstroth beehives.

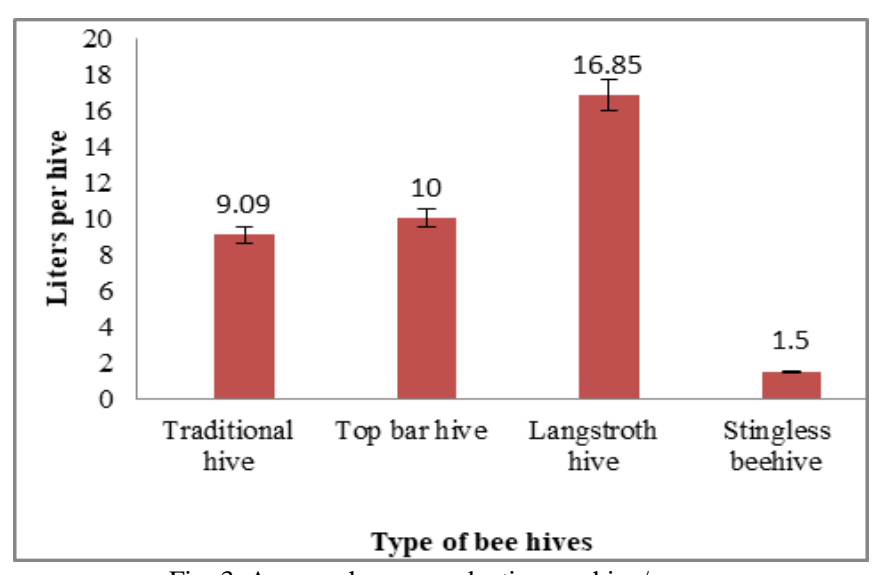

Fig. 3. Average honey production per hive/year.

Beeswax production. The study showed that, majority $(55 \%)$ of the respondents does not produce beeswax, while the rest $(45 \%)$ produce beeswax. It was also reported that, honey is considered as the main product while other products like bees' wax are neglected and wasted, the wax is mostly left or thrown away. During the field visits, it was seen bees wax thrown away in the field. The production of bees' wax is averaging $4.18 \mathrm{~kg}$ per year per producer with a minimum of $1 \mathrm{~kg}$ and a maximum of $15 \mathrm{~kg}$ were mentioned. However, while most respondents reported $0.25 \mathrm{~kg}$ per hive. Other study by [23] found that the average production of bees wax was $0.24 \mathrm{~kg}$ per hive. This implies that, there is little sells of bees' wax something which reduce income to beekeepers as they could earn if they sell other bee products in study areas.

\section{Honey Processing Methods}

The analysis was found that $74.2 \%$ of the respondents in the study area use hands with piece of clothes in honey extraction, $19.2 \%$ of the respondents use honey extractor in honey extraction and it is only reported at South District Unguja. Finding by [24] reported that most of the honey produced in Unguja was extracted by hand with a piece of cloth, wire mesh and coconut which reduce the quality of honey

\section{Storage and Packaging of Honey}

Most beekeepers reported that, they do not store honey primarily because honey is sold immediately after being harvested due to high demand of honey in local areas. It was also found that the common materials that are used for packaging in study areas include plastic bottles of various sizes depending on customer needs. In developing countries, the use of locally available materials for packaging and storage of honey products is more common [25]. In Zambia for instance, beekeepers use calabashes and plastic containers for honey storage. The most common size for packaging honey in Zanzibar is $250 \mathrm{~g}, 0.5 \mathrm{~kg}, 1.0 \mathrm{~kg}$, or $2.0 \mathrm{~kg}$ (Fig. 4) and is sold to retailers or direct to the customer. This result implies that, the demand of honey is higher than production.
In addition, there is no proper way of handling and packaging. These limit the opportunity of regional and international honey trading.

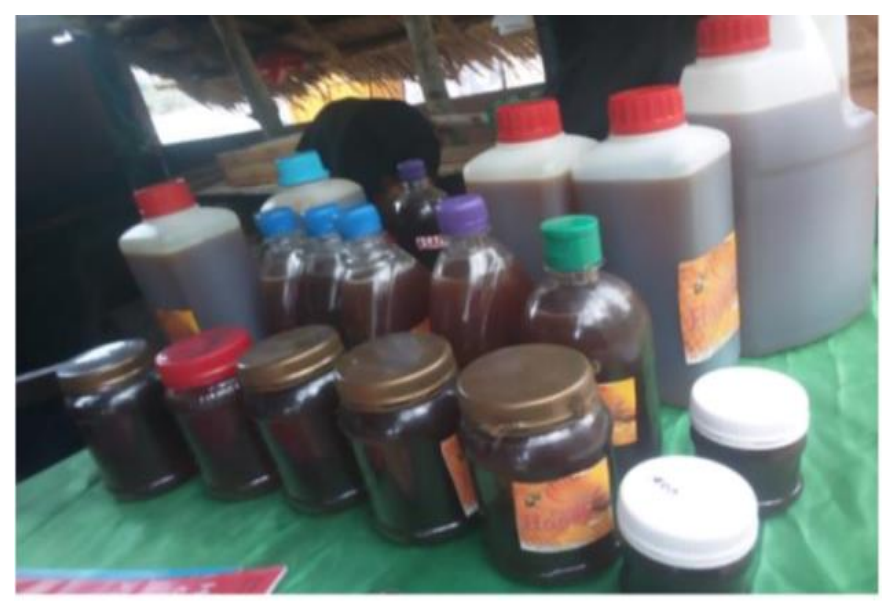

Fig. 4. Packaging materials and weight of honey.

\section{E. Marketing System and Market Channel}

The study has noted that there is no officially organized honey and bees wax market system in the study area. The result indicated that, there are three market channels operated in the study area. The first market channel reported by $77.7 \%$ of the respondents is domestic market direct to consumers Table II. Consumers visit producers at their production sites and buy honey according to their demand. This result correspond with other findings from [26] also reported that, the beekeepers have no specific customers who buy their products. About $84 \%$ of produces sells their honey at village level, $12.8 \%$ to local market and $3.2 \%$ to cooperatives. This implies that, there is a lack of collective honey marketing center that producers could sell their honey in bulk quantity. Honey marketing was done on the producer level on individual contact bases. These reduce the opportunity of trading honey at higher prices. The second channel of honey marketing is wholesalers, $12.3 \%$ of the respondents reported to sell their honey to Organization (ZABA) which is located at Kitogani in Southern District in Unguja. The third channel was found to be followed by $10 \%$ of the respondents. In this channel, the beekeepers opt to sell their honey directly to hotels, whole sellers, and retail shops in urban centers, restaurants, and other consumers in big towns.

TABLE IV: HONEY MARKETING SYSTEM AND CHANNELS

\begin{tabular}{|c|c|c|}
\hline Marketing channel & Frequency & Present \\
\hline Local market direct to consumers & 94 & 77.7 \\
\hline Organisation (ZABA) & & \\
\hline $\begin{array}{l}\text { Hotel, wholesalers, and retail } \\
\text { shops }\end{array}$ & $\begin{array}{l}15 \\
11\end{array}$ & $\begin{array}{l}12.3 \\
10.0\end{array}$ \\
\hline Total & 120 & $100 \%$ \\
\hline
\end{tabular}

\section{F. Price of Honey}

Results from this study shows that, the price of honey varies from one producer to another depending on the type of processing and packaging facilities. The price of locally processed honey ranges from TZS 20,000 to 30,000 equivalent to ( $\$ 9$ to $14 \mathrm{US}$ ) per liter while machine processed honey is T.SH 35,000 to 40,000 (15 to 17 US\$) per liter. This implies that there is an opportunity to sell honey at a higher price if its machines processed. 


\section{G. Consumers}

Consumers are the final operators in the honey and bees wax value chain in the study areas. The major consumers are individuals from local villages, heath vendors and in urban areas, hotels, and restaurants. Consumers tend to buy honey and bees wax from different market channels previously mentioned. They mostly buy directly from producers/beekeepers, organizations such as ZABA, retailers or sometimes wholesalers as per their requirement. Consumers in Zanzibar are entirely satisfied with the quality of honey produced by the beekeepers.

\section{H. Challenges Facing Honey Value Chain in Study Areas}

The study has identified a number of challenges hindering the effective and performance of honey and bees wax value chain in Zanzibar. The most important challenges reported by respondents are inadequate supply of modern beekeeping equipment (23.8\%), inadequate training and extension services (20.5\%), deforestation and forest fires (16.4\%) climate change and variability $(14.8 \%)$. Others are lack of processing machines and honey market center (9\%), pests and pesticide $(8.2 \%)$ lack of capitals $(5.8 \%)$, (Table III). A report by [27] in south District Unguja, [28] in Tanzania, [29] in Nepal explored similar results to this study. This implies that beekeeping industry in many developing countries was hampered with various challenges which result into decrease in yield.

TABLE V: INDICATE CHALLENGES FACING BEEKEEPERS

\begin{tabular}{ccc}
\hline Challenges facing beekeepers & Frequency & Percentage \\
\hline Inadequate supply of modern hive and & 29 & 23.8 \\
equipment & 18 & 14.8 \\
Climate change and variability & 25 & 20.5 \\
In adequate training and extension services & 20 & 16.4 \\
Deforestation and forest fire & 10 & 8.2 \\
Disease's pests and predator & 7 & 5.8 \\
Lack of capitals & 11 & 9.0 \\
Lack of honey processing and marketing center & & \\
& $\mathbf{1 2 0}$ & $\mathbf{1 0 0 . 0}$ \\
\hline
\end{tabular}

The following are the description of challenges:

\section{1) Inadequate supply of modern beekeeping equipment}

This study found that the major constraints facing beekeeping in the study area is the inadequate supply of modern beekeeping equipment. This constraint reported by $23.8 \%$ of respondents in Unguja and Pemba. It should be noted that, effective honey and beeswax production require appropriate beekeeping materials, like modern beehives, bee protective gears and other hive management tools and accessories. Lack of these modern materials is likely to cause a big challenge in adoption of modern beekeeping initiatives; thus, beekeepers may continue using traditional logs which result in low production of honey. During Group discussion, the responses were the same in Mkoani and Wete Pemba whereby they commented that:

“...majority of beekeepers still uses traditional/log hives. This perhaps is due to lack of capital to invest in Modern technology. A modern beehive is more expensive which cost about TZS 230,000 (\$100) compared to traditional/log hives) and lack of technology on using those types of modern Langstroth hives..." (KI 04, Table V).

\section{2) Inadequate training and extension services}

Inadequate training, extension services and lack of opportunities for exposure visits limits beekeepers to adopt improved technology. Tin the whole value chain of honey and bees wax business. This forces beekeepers to use indigenous /traditional knowledge which probably contributes to low production and low quality of honey and beeswax.

"....Besides the training provided by the government and other donors, still reach only few people which forced other beekeepers to rely on traditional beekeeping practices or sometimes copy new technology from trained beekeepers"...(KI 03, Table V).

\section{3) Deforestation and forest fires}

The interview with House Holds reported that, forest fires mainly occur when farmers prepare their land for agriculture and cutting trees for different purposes a practice which affect honey production. This concur with the study done by 30])deforestation and forest fires are major threats to beekeeping practices as it reduces natural habitats and forage for bees. Similarly, the Government official commented that:

... "there is an experience of fire occurrence during dry season in every year from November, December to February which believed to be caused by illegal wild honey collectors and wildlife hunters and during land preparation for agriculture. They left fires and its consequences spread to burn the forest...." (KI 05, (Table V).

\section{4) Climate change and variability}

During Household Interview, it was reported that Climate change and variability appear to be a major concern for agriculture in general and can affect honey production activities. The study conducted by [31] also reported that climate change and variability have been listed as possible contributor to the decline of pollinators. Likewise, pollinators' activities decrease during the period of high rainfall or storms. This restricting bees' activities and forcing them to eat their honey resulting in the possibility of a low harvest [32] In addition, [33] reported that high wind speed can significantly reduce the efficiency of honeybees' search for food. Bees become hesitant to take off from a flower when wind speed is high, and this significantly reduce their efficiency in pollinating flowers

\section{5) Lack of collective market and honey processing centre}

During this study particularly in Pemba, it was found that this challenge forced beekeepers to sell their honey individually at low prices compared to the honey sold in a collection center such as ZABA in Unguja. During the interview with Beekeeping officer (BO) in Pemba, the same problem was mentioned which needs to be resolved. The respondent commended that:

... "There is no specific honey collection and market center where beekeepers could collect their honey in bulk quantities and bulk-marketing; they only sell their honey to passing-by people (wapiti njia). Also, such buyers could not take all produced honey in one time and price per liter was just ranges from TZS 20,000 to 30,000 because each producer sold his/her product independently while there is an 
opportunity to sell at higher price in collective market" .... (KI 03, Table V).

\section{6) Presence of pests, pesticide, and honey predator}

During Household Interview in all districts Unguja and Pemba it was reported that, honey and beeswax production is vulnerable from bee pests and predators. The major pests mentioned by respondents are hive beetles (Aethina sp.), followed by wax moths (Acroia and Galleria spp.), red ants (Solenopsis sp), little black ants (Monomorium minimum) and mites (Varroa destruct) which render the bee colony to abscond the beehive resulting into low honey productivity. This concur with the study done by [34] who reported that, the major honeybee pests and predator were ants, honey badger, wax moth, spider, lizard and birds which affect bee colony and force them to abscond. During the field visit the evidence of pesticide uses was observed and agrochemical to spray on the tomato farm near the mango trees where beehives were kept which likely to affect honeybee (Fig. 5). This result concur with the study done by [35] who reported that, the use of pesticide in other sectors of the economy is becoming important due to the increase of diseases and pests in the production of crops which have marked effect on the life of honey bees' colony. In addition, the study done by [36] report that, chemicals like herbicides and different pesticides application for crop production was ranked by $61 \%$ of the respondents as the first constraint to honey bees.

The opinion from Key Informant Interview was as follows:

“...Most of these chemicals are poisonous for bees and some are extremely dangerous both for bees and for people if they are spread even in a very small amount over a blooming field, they can result in serious destruction of many bee colonies..." (KI 03, Table V).

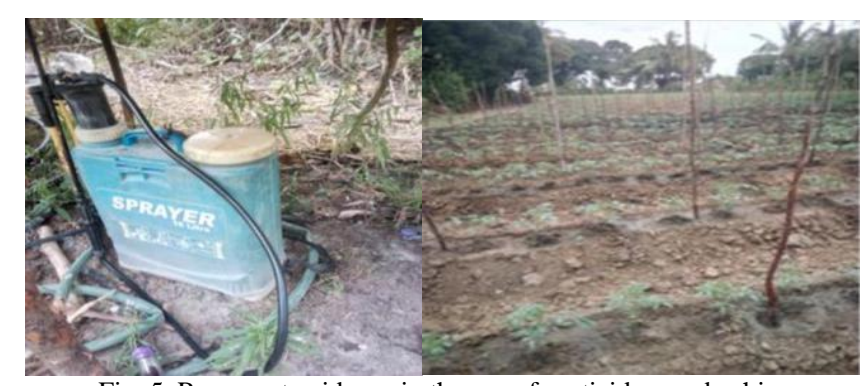

Fig. 5. Represent evidence in the use of pesticide near beehive.

\section{7) Lack of Capital to invest in beekeeping}

About $3.3 \%$ (Table IV) of respondents mentioned a lack of capital as an important challenge towards adopting new technologies. This was also supported by a number of researchers in developing counties like Uganda, Tanzania mainland and Ethiopia. Members in the focus group discussion who claimed that high cost of modern beehives, accessories, and some of the bee equipment such as honey extractors forces them to use mainly local available equipment. The cost of top bar hive varies from Shehia to Shehia and ranges from 40,000 to 100,000 Tanzania Shillings, but for the Langstroth hive, all are provided by donors which costs about TZS 220,000 equivalent to $\$ 100$. During this study, respondents reported that, modern hives are more expensive which make majority of beekeepers to use traditional log hives.

Apart from questionnaires, the researcher also conducted Focus Group Discussion (FGDs) in four study districts including south and north 'B'District Unguja, Mkoani and Wete Pemba. In addition, Interview with Key Informant (KI) such as Zanzibar Beekeeping Association (KI ,01), Pemba Beekeeping Association (KI, 03) Beekeeping Officers (KI, 03) working at district authorities and Shehia leaders (KI, 04) and other Government Officers (KI, 05) to get more information on the challenges that hinder effective and performance of the honey and beeswax value chain in Zanzibar. The findings were summarised in (Table V).

\section{PROFItABILITy ANALYSIS OF DIFFERENT TyPES OF HIVES}

Profitability analysis showed that, the use of modern Langstroth hives were the most profitable business compared to traditional/log hives and top bar hives. The annual net benefit obtained in Langstroth hives is Tanzania Shillings (TZS) 334,536 (US\$ 156) followed by Traditional hives (TZS) 201,434 (US\$ 93) and Top bar hive was the lowest (TZS) 170,392 (US\$ 103). The analysis of Cumulative Revenue for 10 Years per hive is TZS 2,542,418 (US\$ 1,167) for traditional hive, TZS 2,697,787(US\$ 1,292) for top bar hive and TZS 6,277,437 (US\$ 3,033) for Langstroth hive. Following this result, it implies that, the use of modern Langstroth hive has an opportunity to earn more income compared to other types of hives (Table VI).

TABLE VI: RESPONSES FROM FGDS AND Ki ON CHALLENGES THAT Hinder THE DEVELOPMENT OF HoNEY AND BEESWAX VALUE CHAIN IN ZANZIBAR Types of respondents

FGDs - Inadequate supply of modern beekeeping equipment

- Insufficient protective gears

- In adequate training and exposure visit Recommended solution

- Deforestation and forest fire Provide support for modern beekeeping equipment

Provide support for protective gears

Provision of training on modern beekeeping technology and exposure visit to beekeepers

Awareness raising to community on forest conservation and Law enforcement

- Presence of bee pests and predator

- Lack of honey processing and marketing centre

Regular follow up and inspection of beehives

Establishment of honey processing and marketing centre at district or regional level

Key Informant • Unreliable honey marketing centre (KI, 03)* (KI)

- Uses pesticide in their farm land near the bee apiaries $(\mathrm{KI}, 03)^{*}$

- Lack of separate Beekeeping policy $(\mathrm{KI}, 03)^{*}$

- Presence of forest fire during dry seasons $(\mathrm{KI}, 05)^{*}$

- Lack of proper ways of obtaining bee colony (KI, 04)*

- Poor honey processing technique (KI, 01)*

Establishment of honey processing and marketing centre at district or regional level

Raise awareness on the effects of pesticide on honey bees

Government facilitate formulation of beekeeping policy

Awareness to community on forest conservation and Law enforcement

Provide training on the best ways of obtaining bee colony Provide support for processing machines

*A number in brackets indicate type of Key Informant. 
TABLE VII: Summary Of PROFITABILITy ANALysis, COSTS AND REVENUE OBTAINED PER TyPe OF BEEHIVES

\begin{tabular}{|c|c|c|c|c|}
\hline Type of Hive & Unit & Traditional/log hive & Top Bar hive & Langstroth hive \\
\hline Annual quantity of honey produced per hive & Litre & 9.09 & 10 & 16.85 \\
\hline Price per litre for raw honey per & TZS & 26,176 & 26,176 & 0 \\
\hline Price per litre for value added honey & TZS & 0 & 0 & 35.176 \\
\hline Annual Total Revenue for honey per hive & TZS & 237,940 & 261,760 & 591,536 \\
\hline Beeswax production per hive & Kilogram & 0.25 & 0.25 & 0 \\
\hline Price of beeswax per Kilogram & TZS & 15,000 & 15,000 & 0 \\
\hline Annual Total Revenue for Beeswax & TZS & 3,750 & 3,750 & - \\
\hline Annual Total Operational Costs per hive & TZS & 41,343 & 95,118 & 251,000 \\
\hline Annual Gross Revenue per hive & TZS & TZS241,690 & TZS 265,510 & TZS 591,536 \\
\hline Annual Net Revenue per hive & TZS & TZS 201,347 & TZS 170,392 & TZS 334,536 \\
\hline Net Return per TZS Invested per litre & TZS & 8 & 9 & 10 \\
\hline Net Revenue per litres TZS & TZS & 22,150 & 17,352 & 20,000 \\
\hline Cumulative Revenue for 10 Years per hive & TZS & TZS 2,542,418 & TZS 2,697,787 & TZS 6,277,437 \\
\hline
\end{tabular}

*1 US \$ = TZS 2,300.

\section{CONCLUSION AND RECOMMENDATIONS}

\section{A. Conclusion}

Based on the research findings, it was found that, honey and beeswax are important economic activities for livelihood improvement, food security and poverty reduction. However, the study found that the value chain of honey and bees wax is not well developed. Honey and bees wax production is still below the optimum yield. The study also found that, there is a number of challenges which hinder the performance of honey value chain in the study area. The study revealed that, majority of beekeepers still use traditional methods of honey and beeswax production which proved to have low yield compared to modern technology. It is clearly noted that, despite various support and programs implemented to increase honey and beeswax production in Zanzibar, the study depicts that, there has been various challenges that hamper the honey and beeswax value chain. The most common challenges revealed in this study include an inadequate supply of modern beekeeping materials and equipment, inadequate training, deforestation and forest fire, climate change and variability, pests and predator, Lack of organized market center and lack of capital to invest' in honey and beeswax production. Despite various challenges identified in this study there is still an opportunity to increase honey and beeswax yield using modern technology. The results indicate that the use of traditional beehives still dominated in the study area though Langstroth hive produces a higher amount of honey. This indicates that, there is an opportunity to increase honey and beeswax yield using modern Langstroth beehives.

\section{B. Recommendations}

From this study the following measures are recommended:

- Provision of support for modern beekeeping equipment such as modern beehives (Langstroth), which in the study areas proved to have high yield.

- Strengthening capacity to community through technical knowledge and organized exposure visits to other rest beekeepers elsewhere.

- Strengthening access to information on market, finance at all level.

- Taking serious precautions to control deforestation and forest fires that affect the life of bees and their habitat.

- Developing value chain and value addition plan for honey and beeswax such as processing, packaging, labeling and quality testing to attract local and
International honey trade.

\section{ACKNOWLEDGMENT}

I wish to express my sincere gratitude to the Department of Forestry and Non-Renewable Natural Resources for releasing me to pursue this study. My in-depth thanks go to my main supervisors Dr. Rashid Juma Rashid and Dr. Sara A. Khamis for their tireless efforts in giving me guidance, comments, directives, and constructive critics. My sincere thanks should go to a couple of capable skilled staff from the Department of Forestry and Non-Renewable Natural Resources, Zanzibar and communities which provided valuable technical assistance, information, and skilled support throughout my research period.

\section{REFERENCES}

[1] Minja GS. and Nkumilwa TJ. The Role Of Beekeeping On Forest Conservation And Poverty Alleviation In Moshi Rural District, Tanzania. European Scientific Journal, ESJ, 12(23) 2016, p. 366. doi: 10.19044/esj.2016.v12n23p366.

[2] Hecklé R. et al. Beekeeping adoption: A case study of three smallholder farming communities in Baringo County, Kenya. Journal of Agriculture and Rural Development in the Tropics and Subtropics 2018; 119(1), pp. 1-11.

[3] Bradbear N. Bees and their role in forest livelihoods. A guide to the services provided by bees and the sustainable harvesting, processing and marketing of their products. 2009 Available at: https://agris.fao.org/agris-search/search.do?recordID=XF2016039753 (Accessed: 6 October 2021).

[4] Mpinga H. Beekeeping Value Chain Development in Tanzania. Forestry Chronicle, 2016 80(February), pp. 445-446.

[5] Guyo S. and Solomon L. Review on Beekeeping Activities, Opportunities, Challenges and Marketing in Ethiopia. Journal of Harmonized Research in Applied Sciences, 2015; 3(4): 201-214.

[6] Tutuba N. B. and Vanhaverbeke W. Beekeeping in Tanzania: why is beekeeping not commercially viable in Mvomero? Afrika Focus, 2018; 31(1). doi: 10.21825/af.v31i1.9047

[7] DFNR, Unpublished report from the Department of Forestry and NonRenewable Resources Zanzibar 2019.

[8] Julia GDP by economic activity in Zanzibar 2019 Published https://www.statista.com/statistics/1185239/share-of-gdp-byeconomic-activity-in-Zanzibar.

[9] Root L. Improving Beekeeping on Unguja Island Improving Beekeeping on Unguja Island by Larken Talhe Root Project Advisor: Mgeni Rajab Mgeni Acedemic Director: Helen Peeks SIT Zanzibar Fall 2008', 2016 December), pp. 0-40.

[10] Mansour S. N. Effects of Land Use on Hymenoptera Diversity: A Case Study in Southern Unguja Dissertation Submitted in Partial Fulfillment of the Requirements for the Degree of Masters of Science in Biodiversity Conservation of the University of Dodoma. 2013; 108pp

[11] RGoZ, (Revolutionary Government of Zanzibar - 2012). Progressive Report the Economics for Climate Change study for Zanzibar 2017109 pp. 
[12] Kothari C.R. Research Methodology: Methods and Techniques. 2nd Edition, New Age International Publishers, New Delhi. 2004; 401pp

[13] Mwakatobe A. and Mlingwa C. Tanzania-The status of Tanzanian honey Trade- Domestic and International Markets. Tanzania Wildlife Research Institute, Arusha, Tanzania, 2006;0(27), pp. 1-13.

[14] Agera S. I. Role of Beekeeping the Conservation of Forests. European 2011;12:(23) ISSN: $1857-7881$.

[15] Abdalla A., Kairu E., Abdalla Ibrahim Ali Kairu, E. W. Zakia Abubakar M. Mchenga, Islam S. S. Pollination and reproductive relationship of four mangroves species in Zanzibar, Tanzania VL - 5JO - 2016 pp. 3572-3584

[16] Gebru YG. Characterization of Beekeeping Systems and Honey Value Chain, and Effects of Storage Containers and Durations on PhysicoChemical Properties of Honey in Kilte Awlaelo District, Eastern Tigray, Ethiopia . 2015. Debre Zeit, Ethiopia 0011-05-015.

[17] Gebiso T. Adoption of Modern Bee Hive in Arsi Zone of Oromia Region: Determinants and Financial Benefits. Agricultural Sciences, 2015; 06(03), pp. 382-296. doi: 10.4236/as.2015.63038.

[18] Minja G. S. and Nkumilwa, T J. 'The Role of Beekeeping on Forest Conservation And Poverty Alleviation In Moshi Rural District, Tanzania. European Scientific Journal, ESJ, 2016; 12(23), p. 366. doi: 10.19044/esj.2016.v12n23p366.

[19] Omar H. Analysis of honey value chain and honey value adding activities for traditional beekeeping: the case of Kongwa district, Dodoma. A dissertation submitted in partial fulfillment of the requirement for the degree of Master of Science in agricultural economics of Sokoine University of agriculture Morogoro Tanzania. 2010; 88pp.

[20] Gebiso T. Adoption of Modern Bee Hive in Arsi Zone of Oromia Region: Determinants and Financial Benefits. Agricultural Sciences, 2015; 06(03), pp. 382-296. doi: 10.4236/as.2015.63038.

[21] Mansour S. N. Effects of Land Use on Hymenoptera Diversity: A Case Study in Southern Unguja Dissertation Submitted in Partial Fulfillment of the Requirements for the Degree of Masters of Science in Biodiversity Conservation of the University of Dodoma. 2013; 108pp

[22] Uliwa P., Ringo E. and Ng'atigwa V. Honey and Beeswax Value Chain Analysis in Tanzania, 2007; June, p. 101.

[23] Shrestha S. et al. 'Honey value chain Analysis-A case study of gahate Village, Lamjung District of Nepal, researchgate.net, 2017; 4, pp. $107-$ 112. Available at: https://www.researchgate.net/profile/BishnuPandey-8/publication/325194365.

[24] Minja G. S. and Nkumilwa, TJ. 'The Role of Beekeeping on Forest Conservation and Poverty Alleviation In Moshi Rural District, Tanzania. European Scientific Journal, ESJ, 2016; 12(23), p. 366. doi 10.19044/esj.2016.v12n23p366.

[25] Tuell J. K. and Isaacs, R. Weather during bloom affects pollination and yield of highbush blueberry. Journal of Economic Entomology, 2010; 103(3), pp. 557-562. doi: 10.1603/EC09387.

[26] Kleijn D., Berendse F., Smit R., \&Gilissen N. Agri-environmen schemes do not effectively protect biodiversity in Dutch agricultural landscapes. Nature, 2001; 413, 723-725 https://doi.org/10.1038/35099540.

[27] Harris, Ciaran, Eaton, Charlotte, Wright, Paul, Jackson, Emily, Goulson, Dave, Ratnieks, Francis F.L.W. Apis mellifera foraging, insect behavior, insect flight, nectar, nectaries, wind speed, worker honey beesAnimal behavior 2020 v.161 pp. 23-31 ISSN:0003-3472.

[28] Gebru Y. G. Characterization of Beekeeping Systems and Honey Value Chain, and Effects of Storage Containers and Durations on PhysicoChemical Properties of Honey in Kilte Awlaelo District, Eastern Tigray, Ethiopia Debre Zeit, Ethiopia 2015; 0011-05-015.

[29] (FAO) Bees and their role in forest livelihoods. A guide to the services provided by bees and the sustainable harvesting, processing and marketing of their products. Food and Agriculture Organization of the United Nations, Rome, 2009 pp. 51-53.

[30] Gebiso T. Adoption of Modern Bee Hive in Arsi Zone of Oromia Region: Determinants and Financial Benefits. Agricultural Sciences, 2015; 06(03), pp. 382-296. doi: 10.4236/as.2015.63038

[31] Mbeiyererwa A. G. Honey Value Chain Mapping in Njombe and Siha Districts the United Nations Development Program Dar es Salaam 2014. 